化学療法後に根治切除可能となった十二指腸悪性リンパ腫の 1 例

\begin{tabular}{llllll}
\multicolumn{6}{c}{ 大阪府立成人病センター外科 } \\
大東 & 弘明 & 石川 & 治 & 佐々木 & 洋 \\
今岡 & 真義 & 日下部 & 博 & 岩永 & 剛
\end{tabular}

\title{
A CASE REPORT OF CURATIVE RESECTION OF DUODENAL MALIGNANT LYMPHOMA FOLLOWING CHEMOTHERAPY
}

\author{
Hiroaki OOHIGASHI, Osamu ISHIKAWA, You SASAKI, \\ Shingi IMAOKA, Hiroshi KUSAKABE and Takeshi IWANAGA
}

Department of Surgery, Center for Adult Diseses, Osaka

索引用語：十二指晹悪性リンパ腫, 悪性リンパ腫に対する化学療法, cyclophosphamide

はじめに

全悪性リンパ腫のなかで消化管原発のものは 1.7 -5.3\%と報告されて扣り ${ }^{1) ~}$, 十二指腸原発の悪 性リンパ腫は極めてまれなものである。われわれは， 初回手術時には荤頭部, 後腹膜, 大血管への浸潤とリ ンパ節転移のために切除不能であったが, 術後に, cyclophosphamide (以下 CPA)を投与し, 根治切除が 可能となった十二指腸悪性リンパ腫の 1 例を経験し た. 本例は術後12年後の現在む健在であり, その治㞠 方針などについて若干の考察を行ったので以下に報告 する.

症例

症例：31歳, 男性.

職業：工員

主訴：黑色便

家族歴：とくになし。

既往歴：22歳，虫垂炎

現病歴：昭和 48 年 6 月はじめ腹痛と黒色便が数日間 持続し，他院で胃透視にて十二指腸潰瘍と診断され， 抗潰县風の内服治療を受けていた。しかし7月はじめ から悪心, 食思不振む伴らようになり精查を希望して 7 月 6 日に当センターを受診した。その後, 黄㾝执よ び右季肋部痛を来し，7月11日に入院した。 入院時所 見：身長 $170 \mathrm{~cm}$, 体重 $64 \mathrm{~kg}$. 眼球結膜軽度黄染, 表在り ンパ節腫大なし，上腹部おぼび右季肋部に圧痛あるも 睡瘤は触知せず。

$<1986$ 年11月12日受理 >別刷請求先：大東 弘明 干537 大阪市東成区中道 1 丁目 $3-3$ 大阪府立成 人病センター外科
入院時検査成績 : 検血 $\mathrm{RBC} 313 \times 10^{4} / \mathrm{mm}^{3}, \mathrm{Hb} 9.7$ $\mathrm{g} / \mathrm{dl}, \mathrm{WBC} 5,100 / \mathrm{mm}^{3}$

血液化学: GOT 158U, GPT 235U, ALP 375U/L,

T-Bil $4.3 \mathrm{mg} / \mathrm{dl}$ (direct 3.1 , in direct 1.2 ).

便潜血：Guajac 法 (+)

荤内・外分泌能検查：P-S テスト 3 因子低下，50gOGTT：境界型

消化管 $\mathrm{X}$ 線検査：上部消化管透視に㧧いて食道，胃 に異常なく, 注腸に打いて子直腸, 結腸に著变を認ぬ なかった。胆道造影 (DIC) にて胆翼は球状に腫大して いたが結石像はなく, 全般に造影が淡くて総胆管末端 部は不明瞭であった。低緊張十二指腸造影にて C-loop は著明に開大し, 下降脚は内外側ともに不整で進展不 良. 乳頭部の口側に不整形の4 $5 \mathrm{~cm}$ に及ぶクレー ターを認めた。

超音波検查：脞頭部中心に径 $10 \mathrm{~cm}$ 大の腫瘤が認め られた。

十二指腸内視鏡検查：球後部から乳頭にかけて浅い 潰崵が多発し, 凝血が付着. 乳頭部は腫大し開口部に 出血が認められた，潰瘍部の生検と細胞診にて悪性り ンパ腫と診断した。

以上より膵頭部領域から発生した悪性リンパ腫と診 断し，外科に転科し昭和 48 年 7 月 24 日に初回手術を施 行.

手術所見：上中部正中切開にて開腹.腹水を認めず. 肝は腫大するも表面平滑, 胆裏は腫大. 辇頭部を中心 に手挙大の腫瘤が存在し，十二指腸後面の腹大したリ ンパ節 $(13)^{4)}$ の凍結切片において悪性リンパ腫の転移 と診断された。脺頭部の生検による凍結切片で腫場細 
胞の萊組織への浸潤を認められ，腫瘤は後方で上腸間 膜動静脈に浸潤し，後腹膜にびまん性に浸潤し可動性 を欠いていた。 以上の所見より根治切除不能と判断し 病巣よりの出血軽減, 減黄の目的で胃幽門部 $2 / 3$ 切除, 胆譱空腸吻合, 胃空腸吻合術施行.

術後経過：術直後より CPA $500 \mathrm{mg}$ を週 2 回の割合 で静脈内投与を開始した(総計11回)。開始後第 4 週目 以後の超音波検査で腫瘤径の縮小 (約 $1 / 2$ ) が認められ た。第 7 週ごろから白血球, 血小板の減少が著明とな り, CPA の投与を経口で $100 \mathrm{mg} /$ 日と変更し, 輸血(総 量 $6,000 \mathrm{ml}$ ) 施行した. しかし, 消化管出血は持続し, 出血源を除くために再手術を考虑して, CPA $500 \mathrm{mg} \times$ 7 回投与した（図 1 ).

第 2 回手術所見(昭和 48 年11月 6 日)：初回手術に見

図 1 初回手術から再手術までの経過

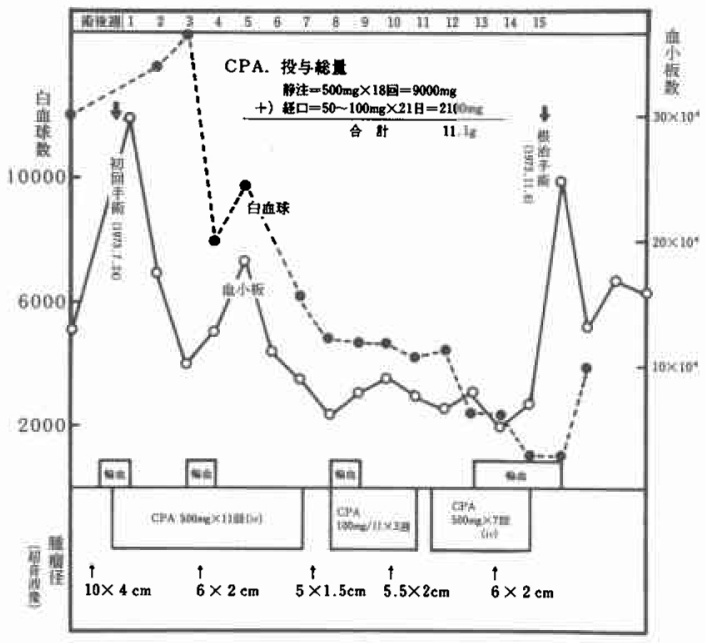

図 2 切除標本：ゾンデは胆管内に挿入

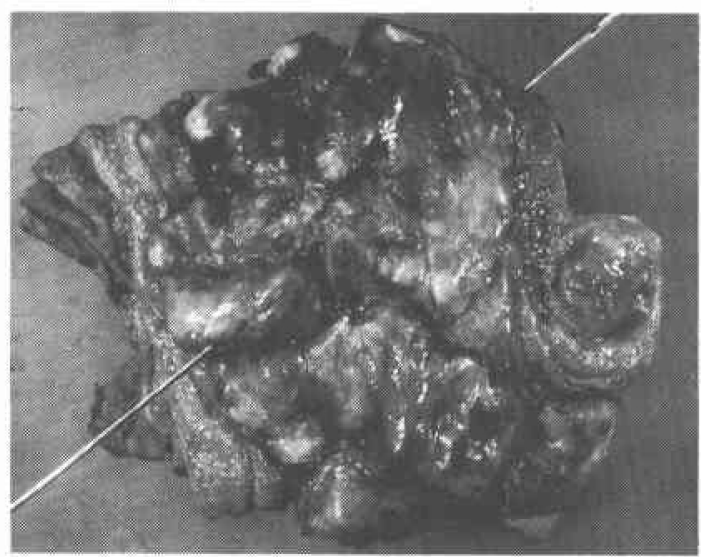

られた，腫場の浸潤による腪頭部の腹大はほ洼正常の 大きさに縮小し，後腹膜，大血管への浸潤も㳗とんど 消失して扣り, 後腹膜からの剶離も比較的容易であっ た．腫大したリンパ節も膵周囲に限局しており，脞頭 十二指腸切除を行った。再建は Child の変法 Roux en $\mathrm{Y}$ 吻合にて行った.

切除標本：十二指腸の粘膜面で乳頭部を中心に全 周 $\times 7.5 \mathrm{~cm}$ の粗大結節状の隆起が認められ, 浅い、潰瘍 を形成（図 2 ).

病理組織所見：腫瘍は十二指腸の粘膜から粘膜下層 を中心として十二指腸全周に進展しわずかに䐙頭部へ の漫潤む認めたが，畽場部の多くは壊死または高度の 変性に陥っていた(図 3). 腫場細胞は主として中型の 大きさで，大小不同が見られ，小数の cleaved cell \& 認められた. diffuse lymphoma, medium sized cell type (LSG 分類) と診断した（図4）.

初回手術時には著しく腫大し, 転移が認められた脺 および大動脈周辺のリンパ節に腫锡細胞は認められ ず，反応性リンパ節腫大のみであった。

図 3 上：十二指腸の腫瘍は多くの部位で壊死 (†) や高度の変性（」）が認められる.

下：上 ( $\downarrow$ )の部位の強扗像. 右側に高度の変性像が 認められる。
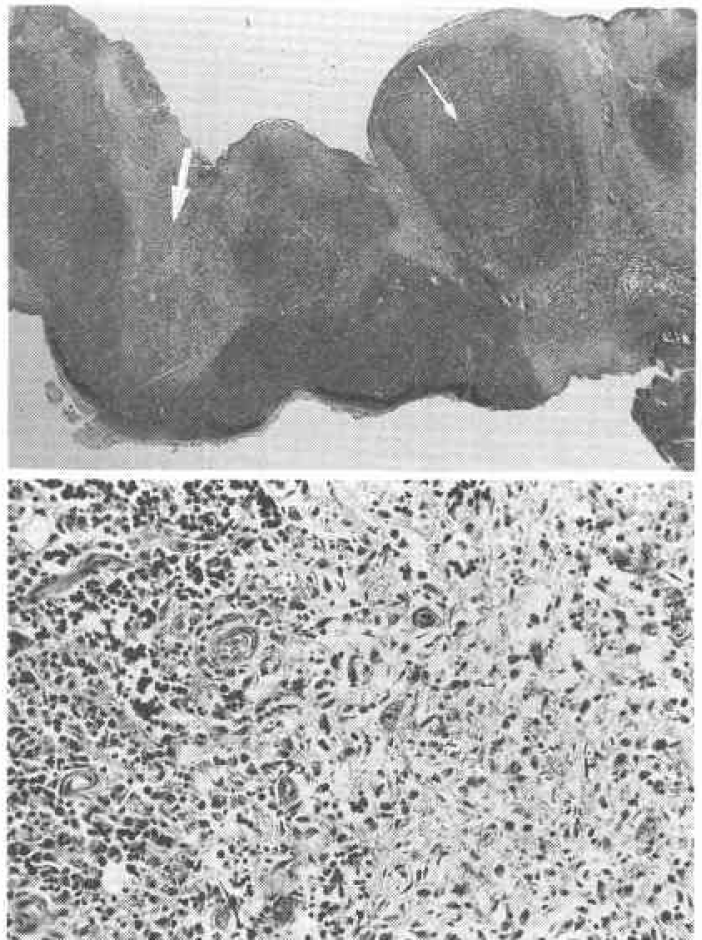
困 4 腫瘍の病理組織像. diffuse, medium sized cell type (LSG 分類)

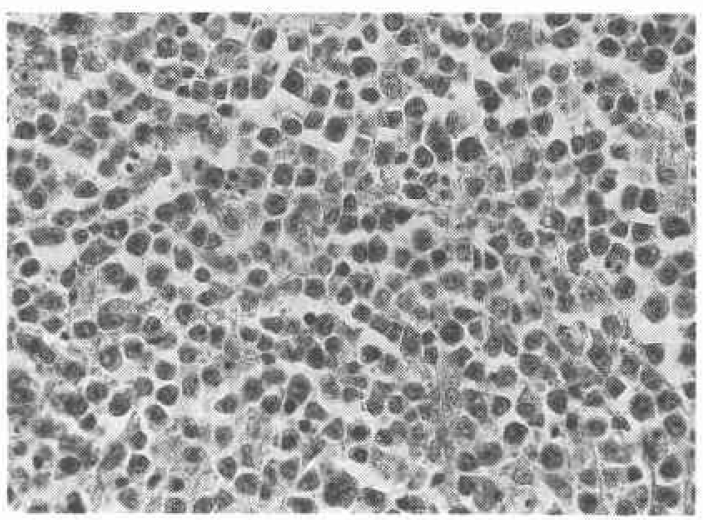

術後経過：術後， 1 年間外来にて CPA $50 \mathrm{mg} / \mathrm{day}$ を経口投与した（総量 $18 \mathrm{~g}$ ）。12年後の現在，患者は再 発なく，健在である。

\section{考察}

Freeman ${ }^{5} は$ extra-nodal malignant lymphoma $の$ 1,467 例を集計し消化管悪性リンパ腫は538例（37\%） であり，その発生部位をみると，胃346例（65\%），小 腸110例（20\%），大腸82例（15\%）の順に多かったと 記している，小腸は，消化管のうち最も悪性腫瘍の発 生の少ない部位であるが，小腸腫瘍の中では悪性リン パ腫が高率で, 中村ら ${ }^{6)} に よ る と ， 68.2 \%$ と報告されて いる。これに対して胃では $1.7 \%$ ，大腸では1.1\%と極 めて低率であったとされている. Marcuse らフは, 小腸 の悪性リンパ腫192例のらち十二指腸原発はわずか 9 例 (4.7\%)であったとしており，十二指腸原発の悪性 リンパ腫は，極めてまれなものである。

消化管悪性リンパ腫は, 全身的な悪性リンパ腫と異 なり切除が極めて有効な治療手段であり，積極的に手 術されることが多い.Freemann ${ }^{5)}$ の集計した1,467例 中，消化管（胃，小腸，大腸）に発生した536例に执い て，手術が施行されたすのは418例 (77.7\%) で，他の 部位に発生した extra-nodal malignant lymphoma 929例の手術施行 457例(49.2\%)にくらべて高率であっ た.とくに胃の悪性リンパ腫の切除率は高く,80〜90\% の頻度之報告されて扮り ${ }^{8) 9}$, 早期の症例では極めて良 好な治療成績が得られている(10)11)。胃に扣ける 5 年生 存率は39 86\% ${ }^{5) 10) \sim 13)}$ であるのにくらべ, 小腸, 大腸で は20 55\%程度 ${ }^{13)}$ と不良である。

その際リンパ節転移が予後を左右するとしている報 告は多く91014)15), 高木ら ${ }^{11}$ は, 癌に準じた郭清が必要
であるとしている，また，深達度，厙煬径も予後を左 右する因子911014)15) と報告されて扣り，とくに他葴器へ の浸潤を認めるものでは, 化学療法や放射線療法を併 用してもその $50 \%$ 生存期間は 1 年末満であるといら報 告が多い(16)17)。なお，組織型と予後については，種々の 報告がなされているが, Shimm ら 八節転移，深達度の程度に相関を認めなかったと報告 している.

ところで十二指腸原発の予後は極めて悪いが")，本 症例のごとく容易に脞へ浸潤し，進行例では後腹膜や 大血管への浸潤，さらに閉塞性黄瘟による全身状態の 悪化などをきたしやすく，手術侵襲る大さいことがそ の原因と考学られる. Najem ら ${ }^{18}$ は，そのほとんどが 切除不能であり, 2 年生存率は $41 \%$, Herrmansen $ら^{19)}$ にいたっては，1年以上の生存はまれであり他の部位 の悪性リンパ腫にくらべ極めて不良であったと報告し ている.したがって, 術後の放射線療法や化学療法の 併用が極めて重要と言光よう。

悪性リンパ腫は放射線に対する感受性が極めて高 く，放射線療法は切除不能例のみならず切除後の再発 防止の手段として広く用いられている(89)15)20) -22). 切除 例に対して術後照射を行い，良好な遠隔成績が得られ ている8)20122)だけでなく，姑息切除例においても放射線 療法を併用することによって治撚切除と同様の治療成 績が得られている(15)18)21). Najem ${ }^{18}$ ) ンパ腫の25例に和いて, 手術単独例の平均生存期間が 8 カ月であったのに対し放射線療法併用例では43カ月 と良好であり, Warren ら ${ }^{21)}$ は十二指腸悪性リンパ腫 に打いては，侵襲の大きい荤頭十二指腸切除を行うよ りも胃腸吻合に放射線療法を併用するほらが良いとし ている.

しかし，Weingard ら 22)は，Stage I〜II の消化管悪 性リンパ腫に対する放射線治療後の再発例に扎いて腹 腔外転移をきたした症例は $55 \%$ であったと報告してい る. 高木 ${ }^{11)}$, 竹中 ${ }^{16)}$, Weingard $ら^{22)}$ はとくに進行例に 怙いては，このような遠隔転移の合併を考慮し，化学 療法を併用するはらが良いとしている。竹中ら ${ }^{161}$ は, 胃の悪性リンパ腫54例を対象として, 術後化学療法の 効果について検討し，すでに所属りンパ節に転移をき たしている症例においてCPA, Vinclistine, Adriamycin, 5-Fluorouracil などの使用によって, そ の $50 \%$ 生存期間は 1 年 6 カ月から 9 年 10 力月一之著し く改善されたと報告している。近年, 種々の多剂併用 療法によりその成績はさらに向上しつつあり ${ }^{22}$, 進行 
例に対しては術後積極的に化学療法, 放射線療法の併 用を考虑するべさであろう。

本症例に扔いては初回手術時, 著明な後腹膜浸潤や リンパ節転移のために根治切除不能で by-pass 手術の みを行い, 術後早期から CPA を開始した。 その後, 超 音波検査によって腫瘍の縮小が確認されていたが，上 部消化管からの出血が著しく, 止血のために再手術が 必要であった，悪性リンパ腫に括いては，腫場の壊死 による穿孔や出血が 9 〜 18\%に認められ，これは胃よ りる腸管に多い(13). 本症例に打汁る大量の出血も制癌 剂による壊死に起因するものであったと考穴られる。 実際, 再手術時には著明な抗腫瘍効果が認められ, 根 治切除が可能となったものであるが, 本症例では初回, 過大な侵襲を伴う切除を行っても姑息手術にかわりな かったはずであり，術後に化学療法を行らよりは，膵， 後腹膜浸潤部などの各病巣への血流が保たれた状態 で，制癌剤の到達を良好に保ちつつ制癌剤を投与した ことが，著明な効果を得た一因と考えられる。とくに， 本症例のよ5に diffuse type の組織型のものは nodular type にくらべ化学療法による緩解率は低い23)とい われておう，すべての悪性リンパ腫において，化学療 法に強い抗腫瘍効果を期待できるわけではないが，化 学療法が根治切除を可能にすることを示したわれわれ の症例は，進行した症例に対する治療方針を示唆する るのと考えられた。

\section{結語}

十二指腸悪性リンバ腫と診断され, 開腹したが, 切 除不能で, by-pass 術のみを行った症例に扔いて，術 後, CPA 投与により著効を得, 再手術において根治切 除が可能となり，13年後の現在も健在である 1 例を経 験したので，若干の文献的考察を加えて報告した。

\section{文献}

1) Loehr J, Mujahed Z, Zahn D et al: Primary lymphoma of the gastrointestinal tract. Ann Surg $170: 232-238,1969$

2) Rosenberg S, Diamond H, Jaslowitz B et al: Lymphoma: A review of 1269 cases. Medicine $40: 31-83,1961$

3) Bush R, Ash C: Primary lymphoma of the gastrointestinal tract. Radiology 92:1349 $-1354,1969$

4）胃癌研究会編：外科・病理。胃癌取扱い規約, 第 10 版, 東京, 金原出版, 1981

5) Freeman $C$, Berg $W$, Cutler $S$ : Occurrence and prognosis of extranodal lymphomas. Cancer $29: 252-260,1972$
6）中村敬夫, 田中貞夫, 佐藤栄一：胃腸管悪性リンパ 腫の病理組織学的検討。癌の臨 $28: 301-306$, 1982

7) Marcuse M, Stout P: Primary lymphosarcoma of the small intestine. Cancer $3: 459$ $-474,1950$

8) Kieffer R, McSwein B, Adkins R: Sarcoma of the gastrointestinal tract: A review of 40 cases. The American Surgeon 48:167-169, 1982

9) Lim E: Factors in the prognosis of gastric lymphoma. Cancer 39:1715-1720, 1977

10) Brooks J, Enterline H: Primary gastric lymphomas. A clinico-pathological study of 58 cases with longterm follow up and literature review. Cancer $51: 701-711,1983$

11）高木国夫, 山本英昭, 岸本秀雄潘か：胃悪性リンパ 腫の手術的治療と成績。胃と腸 $16: 493-501$, 1981

12) Hoerr S, McCormack L, Hertzer N: Prognosis in gastric lymphoma. Arch Surg 107:155 $-158,1973$

13）原田英雄, 林 恭一：Extranodal yン八゚腫の病 態.内科 Mook 17：140-146, 1982

14）中村敬夫：胃腸管悪性りンパ腫の臨床病理学的並 びに免疫組織学的娭討。日消病会誌 79：2221 $-2225,1982$

15) Shimm D, Dosoretz $D$, Anderson $T$ et al: Primary gastric lymphoma. An analysis with emphasis on prognostic factors and radiation therapy. Cancer 46:215-222, 1980

16）竹中武昭, 近田千寻, 坂野輝夫经か：胃原発覀性》 ンパ腫の治療. 多剤併用化学療法の意義を中心に。 日癌治療会誌 $16: 1310-1316,1981$

17) Rao A, Kagan A, Potyk D et al: Management of gastrointestinal lymphoma. Am J Oncol 7 : $212-219,1984$

18) Najem A, Porcaro J, Rush B: Primary nonHodgikin's lymphoma of the duodenum. Case report and literature review. Cancer $54: 895$ $-898,1984$

19) Herrmansen C, Nielsen H : Primary malignant lymphoma of the duodenum. Acta Chir Scand 147: 303-304, 1981

20) Shiu M, Karas M, Nisce L et al : Management of primary gastric lymphoma. Ann Surg 195 : 196-202, 1982

21) Warren $\mathrm{K}$ : Malignant lymphoma of the duodenum,small intestine and colon. Surg Clin North Am 39: 725-735, 1959

22) Weingard D, Decosse J, Sherlock $P$ et al: Primary gastric lymphoma: A 30-year review. Cancer 49:1258-1265, 1982

23）下山正徳, 吉田茂昭, 湊 啓輔ほか：胃悪性リンパ 腫の化学㙩法. 胃と腸 $16: 503-517 ， 1981$ 